\title{
ADIWIYATA PROGRAM FOR STUDENTS IN THE STUDY OF PSYCHOLOGY OF LEARNING AND ECOLOGICAL COUNSELING GUIDANCE
}

\author{
Nur Azizah \\ State Islamic Institute of Purwokerto, Indonesia \\ E-mail:nurazizah@,iainpurwokerto.ac.id
}

Adhitya Ridwan Budhi Prasetyo Nugroho

State Islamic Institute of Purwokerto, Indonesia

E-mail:adbityabudbi41@gmail.com

C 2020 by the authors. Submitted for possible open access publication under the terms and conditions of the Creative Commons Attribution-ShareAlike 4.0 International License (CC-BY-SA) license (https://creativecommons.org/licenses/by-sa/4.0/)

doi $D O I:$ http://dx.doi.org/10.30983/educative.v5i2.3196

Submission : November 11, 2020 $\quad$ Revised: November 20, $2020 \quad$ Published: December 31, 2020

\begin{abstract}
Researchers have conducted studies on the planning, implementation, management and evaluation of the Adiwiyata program in the context of school activities. However, a specific analysis has not been identified in the field of Learning Psychology and Environmental Counseling. The aim of this study is therefore to analyze the Adiwiyata program in the study of Learning Psychology and Ecological Guidance. This literature study was conducted by analyzing the primary sources of the Regulation of the Minister of the Environment of the Republic of Indonesia No. 05 of 2013 on the Guidelines for the Implementation of the Adiwiyata Program and No. P.52/Menlhk/Setjen/Kum.1/9/2019 on the Movement of Environmental Care and Culture in Schools (PBLHS Movement). The results showed that the psychology of learning of the Adiwiyata programme could be integrated into the learning process as well as educational facilities for students using the school environment by considering the psychological development of the students. In the meantime, the Adiwiyata program in the study of ecological counseling guidance can be internalized in creating programs or applied in guidance and counseling services for students to solve the problems and to form students' self-awareness and environmental awareness.
\end{abstract}

Keywords: adiwiyata program, psychology of learning, ecological counseling guidance.

\section{Abstrak}

Kajian penerapan program Adiwiyata mulai dari perencanaan, pelaksanaan, pengelolaan, serta evaluasi maupun penerapan dalam kegiatan di sekolah telah banyak dilakukan. Namun belum ditemukan analisis spesifik dalam kajian psikologi belajar dan bimbingan konseling ekologi. Oleh karena itu, penelitian ini bertujuan menganalisis program Adiwiyata bagi siswa dalam kajian psikologi belajar dan bimbingan konseling ekologi. Metode yang digunakan adalah studi kepustakaan dengan menganalisis sumber primer dari Peraturan Menteri Lingkungan Hidup Republik. Indonesia Nomor 05 Tahun 2013 Tentang Pedoman Pelaksanaan Program Adiviyata dan Nomor P.52/Menlbk/Setjen/Kum.1/9/2019 Tentang Gerakan Peduli dan Berbudaya Lingkungan Hidup di Sekolah (Gerakan PBLHS). Hasil penelitian menunjukekan program Adiwiyata berdasarkan kajian psikologi belajar dapat diintegrasikan dalam proses belajar mengajar maupun sarana edukasi siswa melalui pemanfaatan lingkungan sekolah dengan mempertimbangkan perkembangan psikologis siswa. Sedangkan Program Adiwiyata dalam kajian bimbingan konseling ekologi bisa diinternalisasi dalam pembuatan program maupun diaplikasikan dalam layanan bimbingan dan konseling bagi siswa untuk. mendapatkan solusi atas masalahnya maupun membentuk. kesadaran diri siswa maupun kesadaran pada lingkungan.

Kata kunci: program adiwiyata, psikologi belajar, bimbingan konseling ekologi. 


\section{Introduction}

Human's daily activities in their environment are one of the determinants of quality in the environment. Environmental damage has an important role to play in addressing the needs of restoring the quality of the environment and preserving nature. ${ }^{1}$ The lack of understanding of the importance of the environment for humans has led them to engage in negative environmental activities, such as large-scale exploitation, which can cause environmental damage in the form of environmental pollution and depletion of natural resources. ${ }^{2}$

Environmental damage is becoming a phenomenon and social symptoms that often occur in many regions of Indonesia. ${ }^{3}$ Environmental damage has impacts in various sectors, especially the education sector for environmental sustainability in schools.

School is a facility to educate students to know and understand the importance of preserving the environment. An environment that is in a well-preserved condition is able to create a conducive teaching and learning process and increasing the awareness of school members to participate in conservation, preserve the environment and sustainable development. ${ }^{4}$

Responding to environmental conditions in schools at the Ministry of the Environment and Forestry of the Republic of Indonesia, issued Regulation No 05 of 2013 of the Minister of the Environment of the Republic of Indonesia on the guidelines for the implementation of the Adiwiyata Program and No P.52/Menlhk/Setjen/Kum.1/9/2019 on the care and environmental culture of schools (PBLHS

Movement).

1 Rizky Dewi Iswari and Suyud W. Utomo, "Evaluasi Penerapan Program Adiwiyata Untuk Membentuk Perilaku Peduli Lingkungan Di Kalangan Siswa (Kasus: SMA Negeri 9 Tangerang Selatan Dan MA Negeri 1 Serpong)," Jurnal Ilmu Lingkungan 15, p. 1 (2017): 35-41, https://doi.org/10.14710/jil.15.1.35-41.

2 Marsiana Lina, Masluyah Suib, and Usman Radiana, "Pengelolaan Sekolah Adiwiyata Oleh Kepala Sekolah Di Sekolah Menengah Pertama Negeri 02 Ngabang, Jurnal Pendidikan Dan Pembelajaran Khatulistiwa," Jurnal Pendidikan Dan Pembelajaran Khatulistiwa 5, no. 10 (2016): p.1-17,
Adiwiyata Program in 2013 Ministerial Regulation Number 05 Article 1 is a programme for the development of a careful and environmental cultured school. Schools are required to develop environmental awareness both inside and outside the school.

In accordance with Ministerial Regulation No. P.52/ Menlhk/ Setjen/ Kum.1 /9 /2019 Article that the Caring Movement and the Environmental Cultured in Schools Program (PBLHS Movement) must be implemented with full awareness, sincerity, and support in the program of careful environmental thinking. This behavior is a manifestation of the behavior of the school. The purpose of this Regulation is to increase knowledge, change attitudes, awareness of the need to take real action individually or in conjunction with the community, environmental care organizations and various elements that are useful for present and future generations in dealing with environmental issues for sustainable development.

Articles 4 (1 and 2) and Ministerial Regulation No. P.52/Menlhk/Setjen/Kum.1/9/2019 Article 3 Paragraphs (1) and (2) state that the Adiwiyata program is applied at all levels of primary and secondary education to ensure that all levels of education implement the Adiwiyata program. In the meantime, the evaluation of the Adiwiyata Program is also carried out in a number of phases, starting from the Regency or the City, Province and National.

The Adiwiyata concept is not only applied in Indonesia but it is also in various countries such as Scandinavia, Germany, England, the United States, and other countries with similar programs, named Education

https://jurnal.untan.ac.id/index.php/jpdpb/article/vie $\mathrm{w} / 17009$.

3 Limawati Limawati, "Implementasi Program Sekolah Adiwiyata Di Sekolah Dasar," Wiyata Dharma: Jurnal Penelitian Dan Evaluasi Pendidikan 6, no. 1 (2018): 20-24, https://doi.org/10.30738/wd.v6i1.3355.

4 Indah Kusuma Pradini, Bedjo Sudjanto, and Nurjannah Nurjannah, "Implementasi Program Sekolah Adiwiyata Dalam Peningkatan Mutu Pendidikan Di SDN Tanah Tinggi 3 Kota Tangerang," JGG-Jurnal Green Growth Dan Manajemen Lingkungan 7, no. 2 (2018): 11232, https:/ / doi.org/10.21009/jgg.072.03 
Outside the Classroom (EOtC). The EOtC teaching and learning process takes place outside the school in one or more days a week to complement their classroom study. The places used in EOtC are forests, school parks, museums and anywhere in the world. The goal of $\mathrm{EOtC}$ is to create a different sphere during school days and to promote learning activities, positive social relations, motivation for schools and psychosocial well-being, and EOtC includes some student activities such as problem-solving, hands-on experiments and peer collaboration. ${ }^{5}$

The aim of the Adiwiyata programme is to increase the sense of responsibility and care for the elements of the school (residents) in order to insure that the environmental quality of the school and the environment around the school is maintained and improved. ${ }^{6}$ The Adiwiyata programme is designed to provide positive impacts for school students that green school yards can improve social relations between students and teachers, increase the environmental awareness of school residents, increase learning opportunities, increase academic performance, increase physical activity and improve health. ${ }^{7}$ Contact with nature resulted in a significant positive improvement for students and indicated a negative reduction in student mood improvement. ${ }^{8}$ It is reinforced that there is a positive relationship with nature by having a conservative behaviour that connects students with nature, which is also important for students in the future. ${ }^{9}$

The implementation of the Adiwiyata programme in schools, accompanied by the development of a school culture with environmental insights that are part of school policies, learning curricula, programmes and implementation of extracurricular activities, as well as the availability of school infrastructure have been demonstrated in several previous studies. $^{10}$ Adiwiyata program shows that students have attitudes and behaviors in line with environmental culture, cognitive understanding of environmental education, and students are able to develop student skills, creativity, and productivity. ${ }^{11}$ The Adiwiyata Program also develops participatory aspects based on activities that give a positive contribution to create a good situations and conditions in developing the environmental awareness. ${ }^{12}$ However, none of those studies have discussed the Adiwiyata program according to learning psychology and ecological counseling guidance specifically. It is hoped that the results of this study can develop studies related to Adiwiyata program analysis.

In its implementation, the Adiwiyata program also has a psychological impact on all elements of the school. The place inhabited,
${ }^{5}$ Mads Bølling et al., "Association of Education Outside the Classroom and Pupils' Psychosocial WellBeing: Results From a School Year Implementation," Journal Of School Health 89, no. 3 (2019): p.210-18, https://doi.org/10.1111/josh.12730.

6 Menteri Lingkungan Hidup dan Kehutanan Republik Indonesia, "Peraturan Menteri Lingkungan Hidup Dan Kehutanan Republik Indonesia" (2019), Peraturan Menteri Lingkungan Hidup dan Kehutanan Republik Indonesia No. P.52/MENLHK/SETJEN/KUM.1/9/2019 Tentang Gerakan Peduli dan Berbudaya Lingkungan Hidup di Sekolah.

Christina Kelz, Gary William Evans, and Kathrin Röderer, "The Restorative Effects of Redesigning the Schoolyard: A Multi-Methodological, Quasi-Experimental Study in Rural Austrian Middle Schools," Environment and Behavior 47, no. 2 (2015), https://doi.org/10.1177/0013916513510528.

${ }^{8}$ Colin A. Capaldi et al., "Flourishing in Nature: A Review of the Benefits of Connecting with Nature and Its Application as a Wellbeing Intervention,"
International Journal of Wellbeing 5, no. 4 (2015), https://doi.org/10.5502/ijw.v5i4.449.

9 Joelene Hughes, Miles Richardson, and Ryan Lumber, "Evaluating Connection to Nature and the Relationship with Conservation Behaviour in Children," Journal for Nature Conservation 45 (2018): p.11-19, https://doi.org/10.1016/j.jnc.2018.07.004.

10 Bayu Indra Permana and Nurul Ulfatin, "Budaya Sekolah Berwawasan Lingkungan Pada Sekolah Adiwiyata Mandiri," Ilmu Pendidikan: Jurnal Kajian Teori Dan Praktik Kependidikan 3, no. 1 (2018): 11-21, https://doi.org/10.17977/um027v3i12018p011.

11 Siswanto Siswanto et al., "Environmental Cultured Education and Its Implication on the Student's Competencies in an Adiwiyata School," Cakrawala Pendidikan: Jurnal Ilmiah Pendidikan 38, no. 3 (2019):

https://doi.org/10.21831/cp.v38i3.23154. p.552-64,

12 Muhammad Khairul Yasin, "Character Education for Environmental Awareness through the Adiwiyata Program," Islamic Studies Journal for Social Transformation 3, no. 2 (2019): p.127-45, https://doi.org/10.28918/isjoust.v3i2.2265. 
whether in urban or rural areas, buildings or the natural environment, may also have a direct impact on individual behavior. ${ }^{13}$ In order to fill the research gaps, the aim of this study is to analyse the Adiwiyata programme in the study of Learning Psychology and Ecological Counseling on the basis of the Ministerial Regulation on the Environment of the Republic of Indonesia Number 05 of 2013 on the Guidelines for the Implementation of the Adiwiyata Program and Number P.52/Menlhk/Setjen/Kum.1/9/9/2019 on Caring Movement and Environm (PBLHS Movement).

Psychology of Learning is a branch of psychology that discusses and analyses the basics and principles of human behaviour in the teaching and learning process. Psychology of learning is indispensable for teachers and people engaged in teaching activities in the world of education, with the aim of being able to make decisions and solve the problems associated with learning problems, and of being able to consider the psychology of school students and the psychology of learning, really helps teachers to be mature and empowered when they engage in learning. ${ }^{14}$

Psychology of learning is widely applied in learning activities, consisting of first, behaviourism theory, which takes the view that certain phenomena in the environment have a significant influence on human behaviour, which provides human learning experiences. Second, cognitive theory, which has the point of view to gain understanding, and then to organize cognitive and perceptual aspects. Third, the theory of humanism, which has a point of view when the learning process begins, is used to treat humans as human beings. Fourthly, cybernetics is the theory that the learning process is determined by information. Fifth, constructivist theory, which states that learning is an activity to develop knowledge from self-experience, self-reflection, collaboration, and interpretation. ${ }^{15}$

The psychology of learning theory behind this research, which relates to the implementation of the Adiwiyata program, is a behavioral theory that says that the environment has an influence on the learning process. This behavioral theory states that learning plays a role in explaining human behavior that is formed by stimulus (stimulation) that produces reactive (response) in the form of mechanical laws. ${ }^{16}$ This behavioristic theory focuses on human behavior with an objective, materialistic, and mechanistic approach. According to this theory, an important part of the input lies in the stimulus received, while the output is the resulted response. The stimulus is given by the teacher for the students, while the response is the form of reaction (response) from students after getting a stimulus from the teacher. The emphasis of this theory lies in scientific studies related to the observed behavioral responses as the environment has influences on them. That way, individual behavior is focused on the relative relationship with the environment that can be observed or measured. ${ }^{17}$

Learning according to behaviorism occurs because of the ordering. The relationship between the impressions received by the five senses that act to act or do something interacts with stimulus interactions and responses. Learning is an attempt to revive the interaction of stimulus (stimulation) with as many responses as possible. Behaviorism is a part (flow) that exists in psychology where many of them are seen from the physical phenomenon as well as neglected mental aspects such as intelligence, abilities (talents),
${ }^{13}$ Isabella Bower, Richard Tucker, and Peter G. Enticott, "Impact of Built Environment Design on Emotion Measured via Neurophysiological Correlates and Subjective Indicators: A Systematic Review," Journal of Environmental Psychology 66 (2019), https://doi.org/10.1016/j.jenvp.2019.101344.

14 Syarifan Nurjan, Psikologi Belajar, ed. Wahyudi Setiawan (Ponorogo: Wade Group, 2016).

15 Indah Kosmiyah, Belajar Dan Pembelajaran (Yogyakarta: Teras, 2012).
16 Eni Fariyatul Fahyuni and Istikomah Istikomah, Psikologi Belajar \& Mengajar (Kunci Sukses Guru Dalam Interaksi Edukatif) (Sidoarjo: Nizamia Learning Center, 2016).

${ }^{17}$ Novi Irwan Nahar, "Penerapan Teori Belajar Behavioristik Dalam Proses Pembelajaran," Nusantara (Jurnal Ilmu Pengetabuan Sosial) 1, no. 1 (2016), http://jurnal.um-

tapsel.ac.id/index.php/nusantara/article/view/94. 
interests and individual feelings in the teaching and learning process. ${ }^{18}$

The characteristics of behavioristic learning theory are: First, focus on behavior (actions) that humans do, both from actions and behavior based on truth. Second, all actions or behavior (actions) that are done or returned to reflex. Reflex action is an unconscious individual reaction. Third, individuals develop because of their habits and the results of their educational process. Behaviorism figures include: B.F. Skinner, I.P. Pavlov, E.L. Thorndike, dan J.B. Watson. ${ }^{19}$

The essence of this behavioristic theory is: 1) This behavioristic focuses on learning that is seen from the relationship (interaction) of the stimulus with the response, 2) learning always involves and produces changes in individual behavior (action), 3) mental process are not used and it's not really playing a role in learning, 4) learning in which there are laws that are made to regulate the learning process that is applied to all living things, include humans, 5) living things in their early life have no innate behavior, 6) learning result are obtained from events or external processes which occurs and exists in the environment, 7) the subject here responds only to appropriate stimulus. ${ }^{20}$

Ecology adds emphasis to the functional analysis of existing behaviors in the environment, the suitability of people and the environment, future-oriented cognition, and the relation to one another. ${ }^{21}$ The relationship between one another creates a student interaction both positive and negative. In the implementation of the service, the program, and the ecology-based counseling guidance teaches that environmental issues should be viewed comprehensively. The errors experienced by an individual are not only the fault of the individual, but various things actually can bring a systemic effect. The ecological framework provides a new perspective about the development of the environment, humans, and the interaction between humans and the environment. ${ }^{22}$

Ecological systems framework for counseling focuses on the importance of several things such as: (a) context as the center of client problems (for example, the environment of violence experienced by clients, (b) interactions between clients and the environment around them (for example, environmental changes, cognition, and others), then (c) the meaning or internal representation built by the client in responding their experience in life (for example, unpredictable schemes). ${ }^{23}$

Conceptualization is a concept to understand the meaning, where human behavior is a manifestation of a function of the relationship between a person or individual with their environment. There are three important prepositions. The first preposition is human behavior. The existence of the influence of individual characteristics (personality) and human residence. The second preposition, that human behavior is the result of a process of interaction or relationship between individuals and the environment. The third preposition, human behavior is formed by meaning. This preposition offers a concept or framework comprehensively by providing an offering in psychological services, such as counselors. ${ }^{24}$

\section{Research methods}

This study is a qualitative approach based on the method of literature study. Literature study contains of a series of data collection from various libraries, such as: books, journals,
18 Nahar.

19 Nahar.

20 Dina Amsari and Mudjiran, "Implikasi Teori Belajar E-Thorndike (Behavioristik) Dalam Pembelajaran Matematika," Jurnal Basicedu 2, no. 2 (2018): p.52-60, https://doi.org/10.31004/basicedu.v2i2.168.

21 George B. Richardson, Blair S. Hanson-Cook, and Aurelio José Figueredo, "Bioecological Counseling," Evolutionary Psychological Science 5, no. 4 (2019): p.472-86, https://doi.org/10.1007/s40806-019-00201-4.

22 Moh Khoerul Anwar and Ruly Ningsih, "FaithBase Communities (FBCs) in Ecological Counseling
(EC) to Promote Well-Being (WB) in Millenial Era," Counsellia: Jurnal Bimbingan Dan Konseling 9, no. 1 (2019), https://doi.org/10.25273/counsellia.v9i1.3209.

23 Richardson, Hanson-Cook, and Figueredo, "Bioecological Counseling."

24 Anwar and Ningsih, "Faith-Base Communities (FBCs) in Ecological Counseling (EC) to Promote WellBeing (WB) in Millenial Era." 
reading and taking notes, also processing and analyzing materials. ${ }^{25}$

The primary source used is the Ministerial Regulation of Environment of the Republic of Indonesia Number 05 of 2013 concerning Guidelines for the Implementation of the Adiwiyata Program and Number P.52 / Menlhk/Setjen / Kum.1 / 9/2019 concerning the Caring Movement and Environmental Cultured in Schools program (PBLHS Movement). Meanwhile, secondary sources used are journals and books which are relevant and supportive in conducting the data analysis, and the main object to analyze the Adiwiyata program analysis in the study of psychology of learning and ecological counseling guidance.

This study analyses the research by collecting accurate literature or texts (both from primary and secondary sources) and various other sources, and then arranges them according to study and purpose. After that, a description of each literature is arranged, which is obtained in detail, to be used in the analysis process. The results are then analyzed or interpreted in order to produce a new concept that is easy to understand and in line with the focus of the discussion.

\section{Findings and Discussions \\ Findings}

Adiwiyata programme for student-based Learning Psychology

When the Adiwiyata programme is implemented in schools, it becomes a policy that needs to be pursued, starts with programme planning and can then be included in the content of the Adiwiyata school curriculum so that it can be implemented in a participatory manner with the support of the infrastructure in the curriculum, As set out in Ministerial Regulation No (1). On the basis of the Environmental Education Theory set out in Permen Number P.52/ Menlhk/ Setjen /Kum.1/ 9/ 9/ 2019 Article 1(1) states that the form of care for individuals, organisations and different parties is studied in the socio-cultural field.

Humans are social, not only about the existence of other human beings, but also because of human ecology, like a culturally structured environment, that the material and non-material aspects are an integral part of the relational matrix of human existence. Social learning (including the use of tools) is now an appropriate lesson in building adaptive behavior for individuals.

The implementation of Adiwiyata program is stated in Ministerial Regulation Number P.52 / Menlhk / Setjen / Kum.1 / 9/2019 article 1 paragraph (2), (3), (4), and (5) where students are trained to develop and be able to have a sensitivity to the conditions of the natural environment in the school and its surroundings. Teaching students about biodiversity on school grounds can be done with a series of hands-on practices. Activities that can be carried out by monitoring those in and around the school yard; observing the school's green house, and other activities which are related to nature. Adiwiyata study activities are expected to improve the mental well-being and the mood of students, and improve relations with the environment at school, also make a good utilization of nature, so that students can get inspiration from nature then they will be able to keep a healthy lifestyle in their future. ${ }^{26}$ The implementation of the Adiwiyata program must consider the condition and the enthusiasm of students when studying to achieve the goal of the study.

Adiwiyata program as a form of management and protection for the environment aims to make all living things comfortable in nature, that the quality / comfort variable which called Indoor Environment Quality (IEQ) which consists of thermal comfort, humidity, lighting, air circulation, acoustics, air flow, room ventilation that has a significant influence to the emotions, and a feeling of comfortable with the
25 Supriyadi Supriyadi, "Community of Practitioners: Solusi Alternatif Berbagi Pengetahuan Antar Pustakawan," Lentera Pustaka: Jurnal Kajian Ilmu Perpustakaan, Informasi Dan Kearsipan 2, no. 2 (2016): p.8393, https://doi.org/10.14710/lenpust.v2i2.13476.
26 Deborah J Harvey et al., "Psychological Benefits of a Biodiversity-Focussed Outdoor Learning Program for Primary School Children," Journal of Environmental Psychology p.67 (2020), https://doi.org/10.1016/j.jenvp.2019.101381. 
environmental conditions. ${ }^{27}$ The supportive conditions of learning environment (both inside and outside the classroom) could make students feel comfortable while learning in school.

Adiwiyata Program in Ministerial Regulation Number P.52 / Menlhk / Setjen / Kum.1 / 9/2019 Article 8 is an environmentally friendly school supporter that can be integrated in the learning process both in subjects, extracurricular activities and even in a personal habituation in which consists of strengthening environmentally friendly habituation in schools by finalizing the planning of the PBLS Movement; The implementation of this activity is carried out by making students comfortable when participating the teaching and learning activities and increasing the critical power of students in overcoming problems that exist in school and around.

The establishment and empowerment of Adiwiyata cadres in a Ministerial Regulation Number P.52 / Menlhk / Setjen/ Kum.1/ 9/ 2019 article 8 section (2) contained in learning where students can learn in a specific community environment to introduce new themes and concepts regarding guidance and participation in collective practice in the community, internship learning, and channeling the culture and environment around them. ${ }^{28}$

The relationship between humans and the environment in the learning process can bring up new social possibilities, including the transmission of social knowledge which is very important for the continuity of this knowledge, because it allows changes to the character of individuals, allowing for representations that can be felt by others. This representation is a critical source of knowledge, both within social groups, and in future generations that direct attention to environmental realities. ${ }^{29}$ Learning through the Adiwiyata program can explore students' abilities by utilizing the school environment as a student learning medium.

The Adiwiyata program also aims to build the mindset of school members about the environment around them, where one's mindset about environmental changes has an impact on people's views and actions related to environmental changes. Because, when a person has a mindset that the world will become a significant psychological barrier to making changes to protect and care for the environment, whereas if someone has a developing view of changes in the environment, it can help overcome inaction and environmental adaptation difficulties. ${ }^{30}$ Students who interact with the environment around them will have the ability to analyze in responding and developing learning outcomes.

Adiwiyata program in the study of ecological counseling guidance

The implementation of Adiwiyata program at school for students in Ministerial RegulationNumber P.52/ Menlhk/ Setjen/ Kum.1/ 9/ 2019 article 1 section (13) one of the goals is to shape student self-development by providing opportunities for students to develop themselves and express themselves according to the needs, talents, and interests of students, as well as in accordance with school conditions. Ecological Guidance and Counseling through Guidance and Counseling teachers can integrate program activities and services for students based on ecology for selfdevelopment of students to become a Adiwiyata cadres. From here, students will be ready to participate and take a role both in school and in society.

Student mentoring in schools is also carried out in order to form an Adiwiyata Cadres

${ }^{29}$ Harry Heft, "Perceptual Information of 'An Entirely Different Order': The 'Cultural Environment' in The Senses Considered as Perceptual Systems," Ecological Psychology 29, no. 2 (2017): p.122-45, https://doi.org/10.1080/10407413.2017.1297187.

${ }^{30}$ Lorenzo Duchi et al., "How a Growth Mindset Can Change the Climate: The Power of Implicit Beliefs in Influencing People's View and Action," Journal of Environmental Psychology 70 (2020), https://doi.org/10.1016/j.jenvp.2020.101461. 
for students based on Ministry Regulation number P.52/ Menlhk/ Setjen/ Kum.1/ 9/ 2019 article 1 Section (15), The Adiwiyata cadre was created by the Principal and will later be given coaching, training, and assistance so that they are ready to play an active role in providing education and become a driving force for school residents and local residents to provide education in implementing environmentally friendly behavior.

Ecological counseling guidance in the Adiwiyata program is based on a learning environment to help students to overcome environmental concerns. School counselors need to explore students and the environment in applying the program and the process of providing counseling guidance services. The Adiwiyata program which is environmentally based, takes advantage of guidance and counseling from an ecological perspective, which can help students for maturity, whether individual, social, or spiritual in different ways.

The ecological counseling guidance service program that is integrated in the Adiwiyata program, can be implemented at any levels of education, can be in primary and secondary education to develop students' awareness to care about the environment and others. Ecological support is needed for the development of students' social skills with their environment ${ }^{31}$. School counselor must be able to be creative and innovative in making guidance and counseling programs by utilizing the school environment in applying the Adiwiyata program for students.

The Adiwiyata program can be applied in the implementation of ecology-based counseling guidance services in schools by combine them into counseling guidance services for students. Counseling guidance contributes and develops to ecological problems, so that services and programs can be carried out through participatory based on development activities. The implementation of ecological counseling guidance in schools must also pay attention to several principles, which are student needs and school conditions, so that the benefits of ecological counseling guidance programs and services are obtained by students and all elements in the school.

\section{Discussion}

Adiwiyata program based on Ministerial Regulation number 05 Year 2013 Article 2 has the principles of being educative, participative, and sustainable. Educational principles are applied in learning activities, both in curriculum design and in student learning practices. Meanwhile, the participatory principle shows that the Adiwiyata program can be implemented by all elements in the school, especially students and the community and various parties who participate and support the Adiwiyata program. The purpose of the sustainable principle is that the Adiwiyata program does not only stop at the discourse and program plan, but also continues to be implemented and continues to be developed according to school needs so that the Adiwiyata program continues to run well.

The school environment and all elements in the school are mutually supportive and inseparable, so schools must be able to take advantage of the environment and natural surroundings in the learning process and in implementing ecological counseling guidance services. Initiatives that can be taken to promote student psychosocial well-being are that schools can map and organize suitable places and environments for exploration and problem solving or for educational media, so that students are not too tense and stressed out in classroom learning. ${ }^{32}$ Therefore, learning outside the classroom or outdoors is an alternative or solution to reduce student tension by taking advantage of the school environment. This is in accordance with the connectionism theory of E.L. Thorndike,
31 Laila Maharani, "Dukungan Ekologi Berbasis Perkembangan Sosial Untuk Meningkatkan Kemampuan Keterampilan Sosial Anak," KONSELI : Jurnal Bimbingan Dan Konseling 4, no. 2 (2017), http://www.ejournal.radenintan.ac.id/index.php/konse li/article/view/2402.

32 Bølling et al., "Association of Education Outside the Classroom and Pupils' Psychosocial WellBeing: Results From a School Year Implementation." 
where the Adiwiyata program has a connection with school environment that can support the learning process, which the impression is associated or accepted by the senses and students can learn well, for example studying while enjoying the breeze in front of the class or in a green open space (school garden).

Outdoor learning is also able to generate interest, engage and support children of all learning abilities. In achieving learning objectives, this also has a positive effect on the health and well-being of students. This is supported by the link between education and good health, support for outdoor learning is one of the methods to facilitate students in achieving academic potential, increase educational experience and achievement, and ultimately improve future health outcomes and careers. ${ }^{33}$

Related to Classical Conditioning from JB Watson which applies and conditions the existence of reflex conditioning in emotional responses can be applied in the Adiwiyata program, where schools can condition the students in the learning process, adjusted to student characteristics and school conditions, so that students are able to give meaning and get benefits from the learning process with nature. For example: students are asked to be creative with the use of nature related to the subject matter. Schools can also design the school environment in such a way that it can provide students with motivation and learning space, which can be a solution for students, so they won't get bored because they have been studying in the classroom for too long.

Learning outside the classroom can be a form of stress reduction experienced by students when learning at school. The natural environment is beneficial for human well-being and survival because it automatically generates various psychophysiological responses for stress reduction. Nature can lower stress levels and improve psychophysiological stress relief such as lowering blood pressure and nature can also withstand stress. Based on the experiments in Japan, certain natural elements, such as wood or the sound of splashing water, affect the human stress response. These experiments proved that human contact with nature can lower pulse rates, reduce cortisol levels, and improve immune function, ${ }^{34}$ as well as improve social networking and reduce student aggression. ${ }^{35}$ Learning in schools by utilizing nature can not only be done by natural schools but through the development of the Adiwiyata program this learning can be done in all schools.

Protection and management in the school environment aims to create environmental conduciveness, because with this condition we can build positive emotions in students. Nature breeds positive feelings, so positive feelings must be nurtured and supported. The more time students spend in a safe natural space, the more they appreciate the environment, which then incorporates it into their own sense of self and shows an inherent concern for the environment. Therefore, the relationship between students and the environment has shown an important role in the 'future life trajectory' with the environment because it has a significant impact on the social
33 Emily Marchant et al., "Curriculum-Based Outdoor Learning for Children Aged 9-11: A Qualitative Analysis of Pupils' and Teachers' Views," PLOS ONE 14, no. 5 https://doi.org/10.1371/journal.pone.0212242.
(2019),
${ }^{34}$ Capaldi et al., "Flourishing in Nature: A Review of the Benefits of Connecting with Nature and Its Application as a Wellbeing Intervention."

35 Kelz, Evans, and Röderer, "The Restorative Effects of Redesigning the Schoolyard: A MultiMethodological, Quasi-Experimental Study in Rural Austrian Middle Schools.” 
and emotional well-being of students, ${ }^{36}$ and the natural scenery from the classroom increases student stimulation, reduces boredom in learning, and related to the quality of studying that requires focus and attention, it is better than the quality of studying when students are in a classroom without natural views. So, the schoolyard has the potential to become a place for students to experience a restorative element. ${ }^{37}$ The benefits of learning by maximizing the environment are potentially positive for students because they can increase focus and attention and reduce boredom in studying.

Intellectual development is used to understand the cultural environment that exists around it, where the school counselor has a role in assisting students in carrying out social action in society, this is because teaching technique which is rooted in culture focuses on the life experiences of school youth by 1) recognizing the legitimacy of their cultural heritage, 2) building a relationship between home and school, 3) the value of teaching students' own cultural resources, and 4) integrating nondominant cultural materials into the curriculum. Culture-relevant education is centered on three principles, namely: 1) fostering academic success, 2) developing cultural competencies, and 3) expanding critical awareness. This education maintains culture by supporting young people in maintaining the cultural and linguistic competences of the community, while offering access to dominant cultural competencies. ${ }^{38}$ The application of Ivan Pavlov's theory (Conditioning processes) shows that behavior can be formed by repetition and students are conditioned to have awareness, based on that, the Adiwiyata

36 Sabirah Adams and Shazly Savahl, "Children's Discourses of Natural Spaces: Considerations for Children's Subjective Well-Being," Child Indicators $\begin{array}{lll}\text { Research } & 10 \text { (2017): }\end{array}$ https://doi.org/10.1007/s12187-016-9374-2.

37 Kelz, Evans, and Röderer, "The Restorative Effects of Redesigning the Schoolyard: A Multi- program for students must be socialized, internalized, and conditioned according to the needs of students to form students who have a sense of care and sensitivity in order to always respect and protect the nature.

Monitoring and evaluating the implementation of the PBLHS Movement in Adiwiyata program on Ministerial Regulation Number P.52/ Menlhk/ Setjen/ Kum.1/ 9/ 2019 Article 9 Section (1) and (2) carried out by all elements of the school including: the principal; board of educators; school committee; students; and society. Where all elements of the school and society must always gather, collaborate and develop the Adiwiyata program so that all elements of the school, society, and school environment can benefit from it so that its sustainability is well maintained.

Operant Conditioning Theory from B.F. Skinner is used to predict (program) and control the behavior that will be formed. The habit of participating in the Adiwiyata program for students must also be programmed in an interesting, unique, and innovative way to stimulate students' creative ideas and imaginations, so that the Adiwiyata program goals can be realized because they are also supported by stimuli that appear, so that the responses obtained in appreciating nature or taking advantage of nature can be useful for the student learning process.

It is important to assist students in order not to get caught up in the wrong social experiences and relationships that have an impact on students' psychology in the future. Assisting the students can be done through guidance and counseling programs and services in schools so that guidance and counseling

Methodological, Quasi-Experimental Study in Rural Austrian Middle Schools."

38 Subini Annamma and Deb Morrison, "DisCrit Classroom Ecology: Using Praxis To Dismantle Dysfunctional Education Ecologies," Teaching and Teacher Education 73 (2018): p.70-80, https://doi.org/10.1016/j.tate.2018.03.008. 
teachers can also identify and monitor students' conditions in learning and be able to solve students' problems.

In the study of psychology of learning, the Adiwiyata Program can be implemented in various aspects, including: 1) making clear objectives of the interconnection of learning and the environment. 2) internalizing every element of learning for students, starting from the curriculum, learning program plans, evaluation forms, to the fulfillment of learning facilities. 3) provide full support for all elements in the school in carrying out environmentbased activities. 4) conducting consultations, mentoring and collaborating with related institutions to develop Adiwiyata programs for students, 5) developing Adiwiyata programs for students who have creativity and environmental awareness that involve all elements or domains in the school.

Healthy environmental education is not only for students, but students can also go into the field as educational agents and as Adiwiyata cadres to socialize, invite people to change for the better by changing bad habits of people who do not care about the environment around them, because, currently Nature-based interventions are still underutilized as a mental health strategy, considering that research shows that interventions that connect humans to nature can bring about many positive changes in various functions such as in the aspects of individual cognitive, emotional, spiritual and physical well-being. ${ }^{39}$ Education and reinforcement support for Adiwiyata in P.52/Menlhk/Setjen/Kum.1/9/2019 according to article 11 section (2) and (3) Can come from schools, government agencies or other parties (social organizations, professional organizations, the business world, NGO (Non- governmental Organization), practitioners and experts, Educational Quality Assurance Institutions in government agencies or educational institutions, and so on.

Changes of someone's behavior towards the lack of use of nature is because the encouragement of others who are convincing and have benefits. Breaking community habits also because they focus on the context of changing directions and lifestyles that can provide valuable opportunities to be healthier and more sustainable. ${ }^{40}$ These changes are carried out by socializing and taking an approach about the importance of the environment for human life in order to create a new lifestyle in terms of environmental care. School Counselor can collaborate with all teachers and students in designing, socializing, and utilizing the potential of the school environment for students.

The Adiwiyata program in the study of ecological counseling guidance can be implemented in various aspects, including: 1) identifying student needs by adjusting to school environmental conditions, 2) making creative counseling program plans in accordance with the Adiwiyata program, 3) implementing counseling and Adiwiyata programs that can be done by students, 4) providing assistance for students who have problems with the reinforcement of the Adiwiyata program, 5) doing follow-up guidance and counseling programs in schools that develop students' selfawareness.

Belief in nature shows a contribution to understand the environment, insights, and information gaps in climate change, including the human factor and the lack of action to

Lifestyles: Testing the Habit Discontinuity Hypothesis in a Field Experiment," Journal of Environmental Psychology 45 (2016):

https://doi.org/10.1016/j.jenvp.2015.11.008. 
conserve the environment. ${ }^{41}$ Learning from this, by utilizing the school environment can bring new energy and enthusiasm, for students who need support from all parties and also provide adequate facilities for learning and in providing guidance and counseling services for students.

The school environment can be maximized as a medium and support for all learning activities at school. All forms of intervention and reinforcement provide great support for students, which is applied in the Adiwiyata program which has implications for all components in schools that can contribute to appreciate the environment and the natural surroundings well. Guidance and counseling in schools also spur the school counselor to maximize environmental media for unlimited expression in the guidance and counseling service program for students.

Adiwiyata program in ecological counseling guidance programs and services is expected to be a solution and an education forum in creating an environment for learning and developing students' abilities to respond to the environment around them as a form of responsibility to preserve the environment and maintain student interactions with the environment supported by Adiwiyata program implementation at any levels of education.

\section{Conclusion}

The Adiwiyata program is implemented with the aim of raising awareness of all school elements to create a healthy environment together, because a healthy environment will have a positive impact on school residents, especially students as agents of change and future successors in protecting the surrounding environment. Adiwiyata program is carried out by applying the value of learning psychology and paying attention to the ecological counseling guidance service program, so that this can be carried out properly, of course by paying attention to the students' need and school conditions, because the natural environment contributes to human physical and psychological health.

The implementation of ecological counseling guidance programs and services as a form of environmental conservation efforts, where school counselor can apply counseling guidance programs and services by playing a direct role for students based on the surrounding natural environment, so that ecological counseling guidance programs and services can be implemented and applied in a sustainable manner and all elements of education in schools can be involved in it, so that students are enthusiastic about the environmental education materials using models in the process of school activities.

The implementation of the Adiwiyata program is important for all schools, because of the importance of environmental benefits for the school residents' condition and the Adiwiyata program socialization must be improved, so that the Adiwiyata program can be aligned with the school curriculum, learning process, school activities, and other.

The limitation of this research lies in its discussion which only focuses on analyzing the Ministerial Regulation of Environment of the Republic of Indonesia Number 05 of 2013 concerning Guidelines for the Implementation of the Adiwiyata Program and Number P.52 / Menlhk/ Setjen/ Kum.1/ 9/ 2019 About Caring Movement and Environmental Cultured in school program (PBLHS Movement) in the study of learning psychology and ecological counseling guidance by not

41 Duchi et al., "How a Growth Mindset Can Change the Climate: The Power of Implicit Beliefs in Influencing People's View and Action." 
discussing other studies. This was chosen because the two studies were related to the Adiwiyata program application for students in schools.

Recommendations for future research are expected to be able to study using other methods (both qualitative or quantitative) as well as mix methods with more specific studies that are applied to the students and the teachers in schools and the parents of the students, both from the aspects of learning psychology (student developmental conditions, cognitive, affective, student psychomotor), other research can also be focused by discussing the application of ecological counseling guidance services (such as: individual counseling, group counseling, classical guidance, ecological counseling, and so on), it can also discuss studies based on current conditions and other studies so that it becomes more interesting and unique, and able to produce a lot of research and other scientific works that are useful for scientific development.

\section{References}

\section{Book}

Fahyuni, Eni Fariyatul, and Istikomah Istikomah. Psikologi Belajar \& Mengajar Kunci Sukses Guru Dalam Interaksi Edukatif). Sidoarjo: Nizamia Learning Center, 2016.

Kosmiyah, Indah. Belajar Dan Pembelajaran. Yogyakarta: Teras, 2012.

Nurjan, Syarifan. Psikologi Belajar. Edited by Wahyudi Setiawan. Ponorogo: Wade Group, 2016.

\section{Journal}

Adams, Sabirah, and Shazly Savahl. "Children's Discourses of Natural Spaces: Considerations for Children's Subjective Well-Being." Child Indicators Research 10 (2017): p.423-446. https://doi.org/10.1007/s12187-0169374-2.
Amsari, Dina, and Mudjiran. "Implikasi Teori Belajar E-Thorndike (Behavioristik) Dalam Pembelajaran Matematika." Jurnal Basicedu 2, no. 2 (2018): p.52-60. https://doi.org/10.31004/basicedu.v2i2. 168.

Annamma, Subini, and Deb Morrison. "DisCrit Classroom Ecology: Using Praxis To Dismantle Dysfunctional Education Ecologies." Teaching and Teacher Education 73 (2018): p.70-80. https://doi.org/10.1016/j.tate.2018.03.0 08.

Anwar, Moh Khoerul, and Ruly Ningsih. "Faith-Base Communities (FBCs) in Ecological Counseling (EC) to Promote Well-Being (WB) in Millenial Era." Counsellia: Jurnal Bimbingan Dan Konseling 9, no. https://doi.org/10.25273/counsellia.v9i1 .3209 .

Bølling, Mads, Janni Niclasen, Peter Bentsen, and Glen Nielsen. "Association of Education Outside the Classroom and Pupils' Psychosocial Well-Being: Results From a School Year Implementation." Journal Of School Health 89, no. 3 (2019): p.210-18. https://doi.org/10.1111/josh.12730.

Bower, Isabella, Richard Tucker, and Peter G. Enticott. "Impact of Built Environment Design on Emotion Measured via Neurophysiological Correlates and Subjective Indicators: A Systematic Review." Journal of Environmental Psychology p.66 https://doi.org/10.1016/j.jenvp.2019.10 1344.

Capaldi, Colin A., Holli-Anne Passmore, Elizabeth K. Nisbet, John M. Zelenski, and Raelyne L. Dopko. "Flourishing in Nature: A Review of the Benefits of Connecting with Nature and Its Application as a Wellbeing Intervention." International Journal of Wellbeing 5, no. 4 (2015).

https://doi.org/10.5502/ijw.v5i4.449.

Duchi, Lorenzo, Doug Lombardi, Fred Paas, Sofie M M, and Loyens. "How a Growth Mindset Can Change the Climate: The Power of Implicit Beliefs in Influencing 
People's View and Action." Journal of Environmental Psychology 70 (2020). https://doi.org/10.1016/j.jenvp.2020.10 1461.

Harvey, Deborah J, Louise N. Montgomery, Hannah Harvey, Felix Hall, Alan C. Gange, and Dawn Watling. "Psychological Benefits of a BiodiversityFocussed Outdoor Learning Program for Primary School Children." Journal of Environmental Psychology 67 (2020). https://doi.org/10.1016/j.jenvp.2019.10 1381.

Heft, Harry. "Perceptual Information of 'An Entirely Different Order': The 'Cultural Environment' in The Senses Considered as Perceptual Systems." Ecological Psychology 29, no. 2 (2017): p.122-45. https://doi.org/10.1080/10407413.2017. 1297187.

Hughes, Joelene, Miles Richardson, and Ryan Lumber. "Evaluating Connection to Nature and the Relationship with Conservation Behaviour in Children." Journal for Nature Conservation 45 (2018): p.11-19.

https://doi.org/10.1016/j.jnc.2018.07.00 4.

Indonesia, Menteri Lingkungan Hidup dan Kehutanan Republik. Peraturan Menteri Lingkungan Hidup dan Kehutanan Republik Indonesia (2019). Peraturan Menteri Lingkungan Hidup dan Kehutanan Republik Indonesia No. P.52/MENLHK/SETJEN/KUM.1/9/2 019 Tentang Gerakan Peduli dan Berbudaya Lingkungan Hidup di Sekolah. Iswari, Rizky Dewi, and Suyud W. Utomo. "Evaluasi Penerapan Program Adiwiyata Untuk Membentuk Perilaku Peduli Lingkungan Di Kalangan Siswa (Kasus: SMA Negeri 9 Tangerang Selatan Dan MA Negeri 1 Serpong)." Jurnal Ilmu Lingkungan 15, no. 1 (2017): p.35-41. https://doi.org/10.14710/jil.15.1.35-41.

Kelz, Christina, Gary William Evans, and Kathrin Röderer. "The Restorative Effects of Redesigning the Schoolyard: A Multi-Methodological, QuasiExperimental Study in Rural Austrian Middle Schools." Environment and Behavior
47, no. 2 (2015).

https://doi.org/10.1177/0013916513510 528.

Limawati, Limawati. "Implementasi Program Sekolah Adiwiyata Di Sekolah Dasar." Wiyata Dharma: Jurnal Penelitian Dan Evaluasi Pendidikan 6, no. 1 (2018): p.2024.

https://doi.org/10.30738/wd.v6i1.3355.

Lina, Marsiana, Masluyah Suib, and Usman Radiana. "Pengelolaan Sekolah Adiwiyata Oleh Kepala Sekolah Di Sekolah Menengah Pertama Negeri 02 Ngabang, Jurnal Pendidikan Dan Pembelajaran Khatulistiwa." Jurnal Pendidikan Dan Pembelajaran Khatulistiwa 5, no. 10 (2016): p.1-17.

https://jurnal.untan.ac.id/index.php/jpd $\mathrm{pb} /$ article/view/17009.

Maharani, Laila. "Dukungan Ekologi Berbasis Perkembangan Sosial Untuk Meningkatkan Kemampuan Keterampilan Sosial Anak." KONSELI: Jurnal Bimbingan Dan Konseling 4, no. 2 (2017).

http://www.ejournal.radenintan.ac.id/in dex.php/konseli/article/view/2402.

Marchant, Emily, Charlotte Todd, Roxanne Cooksey, Samuel Dredge, Hope Jones, David Reynolds, Gareth Stratton, Russell Dwyer, Ronan Lyons, and Sinead Brophy. "Curriculum-Based Outdoor Learning for Children Aged 9-11: A Qualitative Analysis of Pupils' and Teachers' Views." PLOS ONE 14, no. 5 (2019). https://doi.org/10.1371/journal.pone.02 12242.

Nahar, Novi Irwan. "Penerapan Teori Belajar Behavioristik Dalam Proses Pembelajaran." Nusantara Jurnal Ilmu Pengetahuan Sosial) 1, no. 1 (2016). http://jurnal.um-

tapsel.ac.id/index.php/nusantara/article/ view/94.

Permana, Bayu Indra, and Nurul Ulfatin. "Budaya Sekolah Berwawasan Lingkungan Pada Sekolah Adiwiyata Mandiri." Ilmu Pendidikan: Jurnal Kajian Teori Dan Praktik Kependidikan 3, no. 1 (2018): p.11-21. https://doi.org/10.17977/um027v3i1201 
8p011.

Pradini, Indah Kusuma, Bedjo Sudjanto, and Nurjannah Nurjannah. "Implementasi Program Sekolah Adiwiyata Dalam Peningkatan Mutu Pendidikan Di SDN Tanah Tinggi 3 Kota Tangerang." JGGJurnal Green Growth Dan Manajemen Lingkungan 7, no. 2 (2018): p.112-32. https://doi.org/10.21009/jgg.072.03.

Richardson, George B., Blair S. Hanson-Cook, and Aurelio José Figueredo. "Bioecological Counseling." Evolutionary Psychological Science 5, no. 4 (2019): p.47286. https://doi.org/10.1007/s40806-01900201-4.

Siswanto, Siswanto, Karimullah Karimullah,

Reni Prasetyawati, and Nurhayati Nurhayati. "Environmental Cultured Education and Its Implication on the Student's Competencies in an Adiwiyata School." Cakrawala Pendidikan: Jurnal Ilmiah Pendidikan 38, no. 3 (2019): p.55264. https://doi.org/10.21831/cp.v38i3.2315 4.

Supriyadi, Supriyadi. "Community of Practitioners: Solusi Alternatif Berbagi
Pengetahuan Antar Pustakawan.” Lentera Pustaka: Jurnal Kajian Ilmu Perpustakaan, Informasi Dan Kearsipan 2, no. 2 (2016): p.83-93.

https://doi.org/10.14710/lenpust.v2i2.1 3476.

Szokolszky, Agnes, and Catherine Read. "Developmental Ecological Psychology and a Coalition of Ecological-Relational Developmental Approaches." Ecological Psychology 30, no. 1 (2018): p.6-38. https://doi.org/10.1080/10407413.2018. 1410409.

Verplanken, Bas, and Deborah Roy. "Empowering Interventions to Promote Sustainable Lifestyles: Testing the Habit Discontinuity Hypothesis in a Field Experiment." Journal of Environmental Psychology 45 (2016): p.127-34. https://doi.org/10.1016/j.jenvp.2015.11. 008.

Yasin, Muhammad Khairul. "Character Education for Environmental Awareness through the Adiwiyata Program." Islamic Studies Journal for Social Transformation 3, no. 2 (2019): p.127-45. https://doi.org/10.28918/isjoust.v3i2.22 65. 